\title{
Discussion: A methodology for regional-scale flood risk
}

\section{assessment}

\author{
B. Gouldby, P. Sayers, J. Mulet-Marti, M. A. A. M. Hassan and D. Benwell
}

Marco Redaelli, Halcrow Group Ltd, Glasgow and Mark Dyer, Trinity College, Dublin

In the presented methodology the flood defence system is split into a series of sections whose structural response to hydraulic loading is considered independent. It is not entirely correct to state that 'research has identified this assumption to be reasonable for defence lengths up to 500,' attributing this conclusion to CUR. ${ }^{11}$ What CUR/TAW ${ }^{11}$ suggests is that over a distance greater than about $500 \mathrm{~m}$ the parameters describing the defence resistance, for example some geotechnical properties, can be regarded as independent. On the basis of this observation, Hall and his co-workers ${ }^{5}$ decided, developing a national-scale methodology, to split defences over $600 \mathrm{~m}$ long into shorter sections and to assume their independency. In Dutch practice, instead, at the scale of closed flood defence systems protecting polders (in the range of $100 \mathrm{~km} \mathrm{long}^{30}$ ), correlations among different sections are taken into account when determining the system reliability. ${ }^{30-32}$ The authors argue that, whereas at national scale the assumed independence in the structural responses of different sections seems a necessary simplification, at regional scale, instead, it is desirable to relax this assumption.

The adopted fragility curves were originally developed ${ }^{12}$ for a national-scale methodology, using the methods of reliability analysis with the intention to address failures by piping through the embankment and by surface erosion from overtopping. The 'weighted creep' formula by Lane, ${ }^{33}$ however, was adopted as limit state function for the piping failure mode. This criterion is valid for piping through the foundation of impervious water-retaining structures and should not be employed in relation to piping through the earthfill.

Foundation erosion and piping through the earthfill are indeed connected to different physical phenomena, ${ }^{34}$ respectively backward erosion and internal erosion, the first being mainly related to the intergranular flow in the ground, the second being related to the flow in cracks, openings and concentrated leakage zones.

As is well known to geotechnical engineers involved in embankment dam risk assessments, the physical process of piping through the earthfill is currently not amenable to credible mathematical modelling. ${ }^{35}$ This implies that the related probabilities of failure need to be determined by engineering judgement elicitation. ${ }^{36}$ An integrated approach to flood risk modelling would require the definition of families of judgement-based fragility curves for the piping through the earthfill mode of failure, reflecting several different embankment conditions. The authors argue that the institution of a cross-disciplinary panel of experts, in charge of a structured process of subjective probabilities elicitation with this aim, should be a priority for the flood risk community in the UK.

Finally the divisions of flood defences into subsections should ideally reflect the geological variability of the underlying ground, which strongly influences potential failure mechanisms. Hence, at an early stage, a geotechnical desk study comprising a review of geological maps and walk over would allow a more effective subdivision of flood defences based on a working geological model for the site.

\section{REFERENCES}

30. VROUWENVELDER A. C. W. M. Spatial effects in reliability analysis of flood protection systems. Proceedings of the 2nd International Forum on Engineering Decision Making, Lake Louise, Canada, 2006.

31. VRIJLING J. K. Probabilistic design of water defense systems in The Netherlands. Reliability Engineering and System Safety, 2001, 174, No. 3, 337-344.

32. Steenbergen H. M. G. M, Lassing B. L., Vrouwenvelder A. C. W. M and WAARTS P. H. Reliability analysis of flood defence systems. Heron, 2004, 49, No. 1, 51-73.

33. LANE E. W. Security from underseepage: masonry dams on earth foundation. Transactions of ASCE, 1935, 100, 12351272.

34. RICHARDS K. S. and REDDY K. R. Critical appraisal of piping phenomena in earth dams. Bulletin of Engineering Geology and the Environment, 2007, 66, No. 4, 381-402.

35. Fell R., Bowles D. S., ANDERSON L. R. and Bell G. The status of methods for estimation of the probability of failure of dams for use in quantitative risk assessment. Proceedings of the 20th ICOLD Congress, Beijing, China, 2000.

36. VICK S. G. Considerations for Estimating Structural Response Probabilities in Dam Safety Risk Analysis. United States Bureau of Reclamation Technical Service Centre, Denver, USA, 1999, USBR Technical Report No. 99D88313040. 


\section{Authors' reply}

The authors are grateful to the discussants for the opportunity to provide clarification on certain points. With regard to spatial correlation of geotechnical parameters, it should be noted that the previously cited Dutch work ${ }^{11,30,31}$ relates to determining the reliability of the defence system; this is quite different from the modelling system that has been described where the defence system states are linked to a hydraulic inundation model, which is then used to determine economic damages over the floodplain area. Nevertheless, it is of course desirable to include information relating the spatial dependencies of the geotechnical parameters within the model, although data that can be used to inform this type of analysis are sparse. It is arguably of more importance to account for the variation in hydraulic loading levels on downstream defences, which arises as a result of upstream defence failures, ${ }^{37}$ a process that is currently excluded. Future developments in this area may well address these issues.

The discussion regarding the use of national-scale fragility curves may be slightly misdirected. Since drafting the manuscript, over 60 different flood defence failure mechanisms and associated limit state equations (LSEs) have been documented in a research report. ${ }^{38}$ These LSEs have been used to form the basis of a software tool that has been used to derive site-specific fragility curves for the Thames model described. ${ }^{39}$ It is preferable to undertake this kind of sitespecific analysis, as stated, than to rely on national curves.

Difficulties relating to modelling the physical processes of earth-fill erosion from piping are described. There has been considerable research in this area that indicates what the discussants suggest is 'well known' by geotechnical engineers may not be agreed by all. ${ }^{40-42}$

If a relevant failure mechanism is identified during a sitespecific analysis for which no mathematical model exists, it maybe necessary to supplement a formal reliability analysis ${ }^{39}$ with subjective judgement. The suggestion to convene a panel of experts to facilitate this process will be viewed by some as impractical. Many will believe the priorities for flood risk management should be decided by consideration of a review covering a broad range of issues, as has recently been undertaken. ${ }^{43}$

The authors agree that, where appropriate, a geotechnical investigation of the site will yield useful information for setting up the model.

\section{REFERENCES}

37. Apel H., Merz B. and ThieKEN A.H. Influence of dike breaches on flood frequency estimation. Computers and Geosciences, 2008 (in press).

38. Allsop W., Kortenhaus A. and Morris M. Failure Mechanisms for Flood Defence Assets. FLOODsite, report T04-06-01, 2006. See http://www.floodsite.net/html/ publications2.asp?ALLdocs $=$ onftSubmit $=$ View for further details.

39. Simm J., Gouldby B., SAYers P., Flikweert J., Wersching M. and BRAMLEY M. Representing fragility of flood and coastal defences: Getting into the detail. Proceedings of Flood Risk 2008, Keble College, Oxford, October 2008.

40. Bonelli S., Brivois O., Borghi R. and Benahmed N. On the modelling of piping erosion. Comptes Rendus Mécanique 2006, 334, 555-559.

41. MoHAmed M. Embankment Breach Formation and Modelling Methods. PhD thesis, The Open University, 2002.

42. Mohamed M., SAmuels P. G., Morris M. W. and Ghataora G. S. Improving the accuracy of prediction of breach formation through embankment dams and flood embankments. In River Flow 2002 (BOUSMAR and ZECH (eds)). Proceedings of the International Conference on Fluvial Hydraulics, Louvain-la-Neuve, Belgium, 2002.

43. PITT SIR M. The Pitt Review: Learning Lessons from the 2007 Floods. Cabinet Office, London, 2008. See http:// www.cabinetoffice.gov.uk/thepittreview/final_report.aspx for further details. 